\title{
INACCURATE VENTIMETRY BY FRESH GAS INLET POSITION
}

\author{
C. BriÈRe, F.R.C.P.(c), J.-G. PATOINe, F.R.C.P.(c), \\ AND R. AUdET, F.R.C.P.(c)"
}

WE hAVE RECENTLY Bought several new Boyle anaesthetic machines (Model M 222) with a $\mathrm{CO}_{2}$ absorber Mark III.

It is a routine in our hospital to monitor patient expiratory volume by placing a Wright ventimeter (Mark XII) on the expiratory limb of the circuit.

When using our new anaesthetic machines we noticed that the ventimeter needle never stopped rotating while measuring expiration. This was more apparent at very high flow of fresh gases. At lower flow, between 4 and $6 \mathrm{~L} / \mathrm{min}$, the expiration was normal, but after a brief delay the ventimeter indicated an added flow of about $200 \mathrm{cc}$.

We found that the inlet for the fresh gases in the breathing circuit was located differently on the new machines.

Figure 1 shows the apparatus and Figure 2 indicates that the fresh gases are introduced directly into the inspiratory $\operatorname{limb}$ between the inspiratory valve and the ventimeter. Formerly this site was used for the oxygen flush.

The change is intended to avoid spillage of fresh gases through the pressure

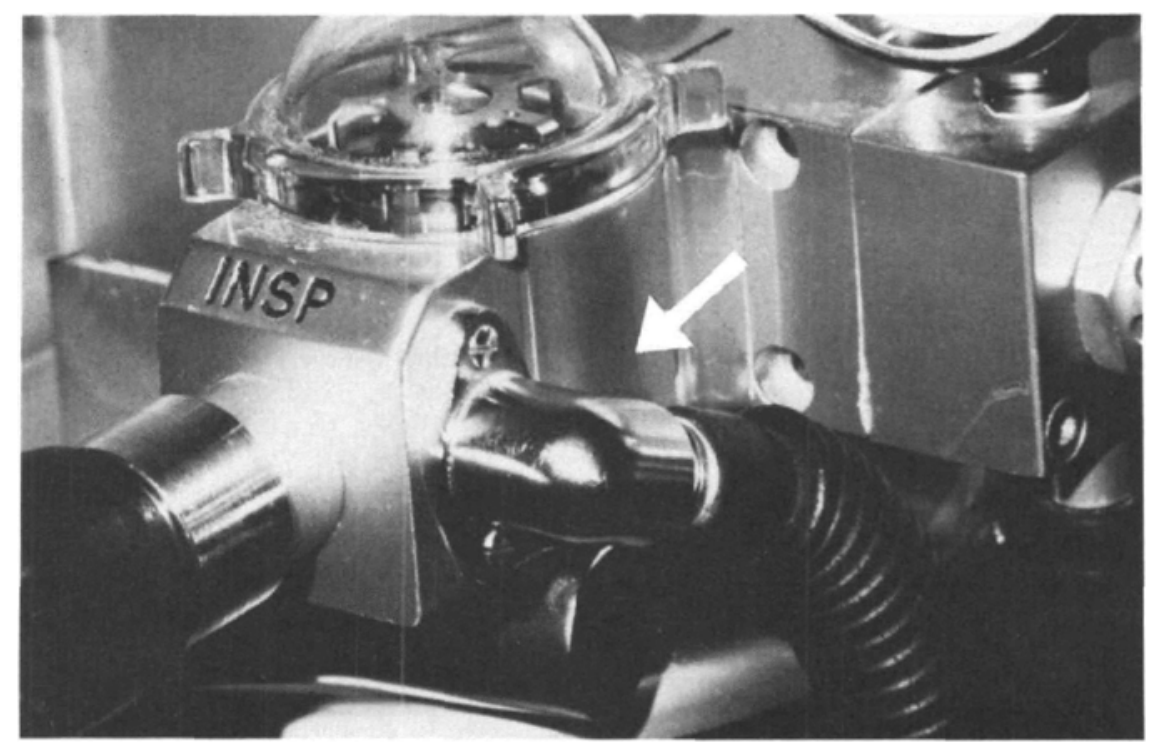

Frgure 1. Picture showing the site of the fresh gas inlet located on the patient side of the inspiratory valve. Formerly this site was used for the oxygen flush in this type of apparatus.

${ }^{\circ}$ From the Department of Anesthesiology, Enfant-Jesus Hospital, Quebec City, P.Q., Canada.

Canad. Anaesth. Soc. J., vol. 21, no. 1, January 1974 


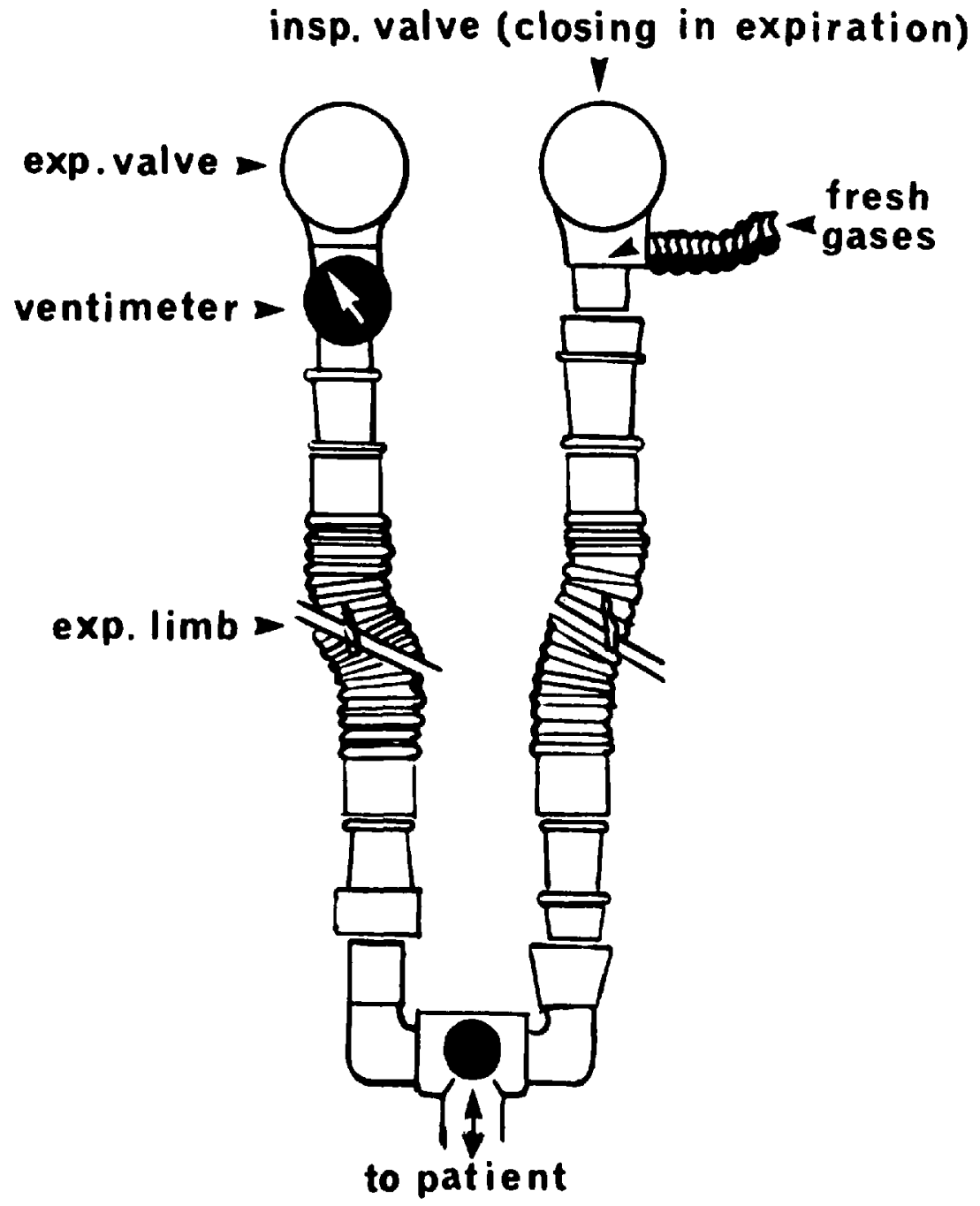

Frgure 2. Fresh gas inlet is on the patient side of the respiratory valve. There is no other valve before the ventimeter creating the admixture of fresh gases with patient expiration and leading to inaccurate reading of the expiratory volume on the ventimeter.

release valve before going to the patient and their dilution with expiratory gases.

Normally during expiration the inspiratory valve closes and only the expired gases are directed to the $\mathrm{CO}_{2}$ absorber through the ventimeter and the expiratory valve. Here, due to the position of the fresh gas inlet there is a certain amount of fresh gases constantly added to the expired volume. This activates the ventimeter continuously.

We reported this anomaly to the manufacturer who promptly corrected it by placing the inlet before the directional valve at the point of the arrow of the inspiratory valve on Figure 2. 


\section{SUMMARY}

A new position is described for the fresh gas inlet on Boyle Anaesthesia Machines (Model M 222) with $\mathrm{CO}_{2}$ absorber Mark III. The location of this inlet between the valves directly in the breathing circuit leads to inaccurate measurement of the expiratory volume when using a Wright ventimeter on the expiratory limb of the circuit.

Correction is made by the manufacturer on request.

\section{RÉSUMÉ}

La position de rentrée des gaz frais sur les appareils d'anesthésie de Type Boyle (Modèle $\mathrm{M} 222$ ) munis d'absorbeur de $\mathrm{CO}_{2}$ Mark III a été modifiée récemment dans le but de permettre leur utilisation au maximum.

Cependant, il devient ainsi impossible de faire une lecture précise du volume expiré parce que les gaz frais pénètrent directement dans le circuit et, selon leur débit, viennent ajouter à la lecture en fin d'expiration. 